ISSN 2338-5324 (print)

ISSN 2442-7276 (online)

Online di http://jkp.fkep.unpad.ac.id

DOI : $10.24198 / \mathrm{jkp}$

\title{
The Distinction of Inhibiting Factors among Patients who Actively and Inactively Participate in Phase II Cardiac Rehabilitation
}

\author{
Megalita Dwika Stevani, Aan Nuraeni, Eka Afrima Sari \\ Faculty of Nursing, Universitas Padjadjaran \\ Email: stephaniemegalita@gmail.com
}

Submitted: 28-9-2017 Accepted: 24-7-2018 Published: 10-8-2018

\begin{abstract}
Cardiac rehabilitation (CR) is an important post-acute management for Cardiovascular Heart Disease (CHD) patients. CR has benefits, such as preventing recurrence and improving patients physically. However, the CR participation rate is low. This condition can produce negative effects, such as recurrence and depression. There are inhibiting factors contribute to the CR participation. The purpose of this study is to identify the distinction of inhibiting factors in patients who actively and inactively participate in phase II CR in Bandung. The result will be as advices to improve policy and nursing intervention to improve the participation number of phase II CR in Bandung. This study used comparative design with cross-sectional approach on 72 respondents who recruited by using purposive sampling at a hospital in Bandung, Indonesia. Data were collected by using Cardiac Rehabilitation Barrier Scale (validity $r=0.46-0.55$ and reliability 0.887 ). Data were analyzed by using descriptive frequency and comparative analysis by using Mann-Whitney. It was showed that there were two significant differences between both of the group in terms of health services aspect ( $p$-value $=0.002)$ and time $(\mathrm{p}$-value $=0.001)$. However there were no significant differences between both of the group in logistics aspect $(p$-value $=0.134)$, and functional status aspect $(p$-value $=0.057)$. It indicates that there were distinctions in inhibiting factors on health services and time aspects. There were differences in the health services, which was related to the lack of CR information and also time aspects, which was related to the lack of CR facilities in remote areas. Therefore, providing information about CR and community or home-based CR are needed.
\end{abstract}

Keywords: Cardiac rehabilitation, CHD, inhibiting factors, participation. 
Megalita : The Distinction of Inhibiting Factors among Patients who Actively and Inactively

\section{Introduction}

Cardiovascular disease, especially coronary heart disease (CHD) is one of the main causes of death in developed and developing countries, including Indonesia (Ministry of Health RI, 2013). By 2015, WHO records about 17 million people worldwide died from cardiovascular disease. And so did in Southeast Asia, coronary heart disease becomes the number one killer (World Health Organization, 2015). The number of CHD patient continues to lift up every year as the increase of instant lifestyle which is bad for the body. In Indonesia, there are about 880 thousand CHD occurrences in 2013 (WHO, 2013). Among many provinces in Indonesia, West Java Province is one with the largest number of coronary heart disease patients, as many as 160 thousand people (Ministry of Health RI, 2013).

According to Indonesian Heart Assossciation (2015), the management of coronary heart disease (CHD) is based on the phase of the disease. In acute phase, when heart attack occurred, pharmacological action (nitroglycerin) and coronary revascularization are usually performed. Then, in post-acute phase, the body's condition, especially heart should be maintained through pharmacology and cardiac rehabilitation.

Cardiac rehabilitation is an important aspect of post-acute patient management. Cardiac rehabilitation consists of physical activities such as treadmill, bicycle ergometer, stretching, and breathing exercise. In addition, there are also dietary control, smoking cessation, and stress management (Olive, 2012; Piotrowicz \& Wolszakiewicz, 2008). To follow cardiac rehabilitation, the patient must meet the indications, which are patients who have a history of unstable angina or chronic ischemic heart disease, and patients who have been taking action of heart reperfusion (fibrinolysis, Percutaneous Coronary Intervention (PCI), or Coronary Artery Bypass Graft (CABG)). Rehabilitation is divided into 4 phases, which are must be done sequentially and continuously. Phase I begins as soon as the patient recovers from CHD and phase II begins when patients have been allowed to do outpatient treatment. To be eligible for doing cardiac rehabilitation phase III and IV independently, patients need to be passed from phase II which is carried out in health facilities, supervised and monitored by health personnel (Scottish Intercollegiate Guidelines Network (SIGN), 2002). Phase II is a transitional phase from hospitalized patient to the outpatient, which has many important benefits. This is the phase that we would discuss about later in this research.

Cardiac rehabilitation has many benefits, such as optimizing the body's physical capacity, providing counseling to patients and families in preventing complications and helping patients to return to their physical activity before the disease. Taylor (2004) stated that cardiac rehabilitation effectively reduces mortality rate, total cholesterol and triglycerides, and decreases systolic pressure on blood pressure. It is also stated that cardiac rehabilitation improves patients' functional status and quality of life (Pasquali, Alexander, Coombs, Lytle, \& Peterson, 2003). Phase II of cardiac rehabilitation is a transitional phase undertaken by outpatients. This phase has some functions, such as controlling the risk, controlling the functional status of patients and being the stage where education and counseling to change lifestyle can be carried out (Radi, Joesoef, \& Kusmana, 2009).

However, the rate of cardiac rehabilitation participation both at worldwide and in Indonesia is still low. There are not many patients actively participate and complete the cardiac rehabilitation program in phase II. Meanwhile, study noted that patients' who inactively participated in cardiac rehabilitation produce a higher probability of depression by about 20\% (Casey, Hughes, Waechter, Josephson, \& Rosneck, 2008). This will certainly affect the quality of life of CHD patients, so that patients tend to be easy to experience deterioration (Nuraeni, Mirwanti, Anna, Prawesti, \& Emaliyawati, 2016). Furthermore, other effects of do not performing or do not completing cardiac rehabilitation are abnormality of heart rate which can be followed by higher risk of recurrence (Chou Lee \& Su, 2014) and lower quality of life, especially in post-PCI and CABG patients (Hutagalung, Susilaningsih, \& Mardhiyah, 2013; Rosidawati, Ibrahim, \& 
Megalita : The Distinction of Inhibiting Factors among Patients who Actively and Inactively

Nuraeni, 2016).

Previous studies stated that, there were 4 main contributing factors for active participation in cardiac rehabilitation including health services, logistics, time, and functional status (Grace, 2011). Health services factor include patients' knowledge and perceptions about cardiac rehabilitation, physician recommendations, and healthcare providers of cardiac rehabilitation programs. Logistic factor includes distance, cost, transportation, weather, and family support. Time factor includes bustle, limited time, and work. Functional status factor includes age, gender, patients' fitness perception, and comorbid disease.

The previous studies identified the description and factors related to cardiac rehabilitation. However, there has been no study comparing the participation of groups who were actively and inactively taking part in cardiac rehabilitation. Harlan (1995) stated that the comparation of inhibiting factor in active group and inactive group showed that gender, occupation, and education have bigger value in the inactive group. The data indicate that those typical characteristics more vulnerable to be inactive person in participating CR program. The comparation of inhibiting factor in active group and inactive group could show how much the factor inhibit patients to participate in cardiac rehabilitation. This is important for nurse for determining the solution to enhance the patients' participation in phase II cardiac rehabilitation.

The purpose of this study was to identify the distinctions of inhibiting factors in active and inactive group patients which are undergoing cardiac rehabilitation. Expectedly, this study can show the distinctions of inhibiting factors in both groups so that it can provide guidance, suggestion, and advise to overcome the problem of low participation rate of cardiac rehabilitation in Indonesia, especially in West Java.

\section{Method}

This study used comparative-descriptive design. It involved 72 cardiac patients who were participating in cardiac rehabilitation phase II and recruited by using purposive sampling. The respondents' calculation was undertaken by using the comparison formula and the selected respondents were divided into 2 groups, those who took part actively in rehabilitation (active group) and those who took part inactively in cardiac rehabilitation (inactive group). Each group has research inclusion criteria, as follows:

\section{a. Criteria for active group:}

i. Participating in phase II cardiac rehabilitation at least 6 meetings regularly

b. Criteria for inactive group:

i. Participating in phase II cardiac rehabilitation less than 6 meetings

ii. Participating in phase II cardiac rehabilitation minimal 6 meetings irregularly iii. Not participating in phase II cardiac rehabilitation when he/she has been declared eligible for cardiac rehabilitation Phase II by cardiologist.

The data were collected by using Cardiac Rehabilitation Barrier Scale questionnaire developed by Sherry L. Grace in 2011 that has been proofed by back translation and done the validity and reliability test. Validity values in the range of $0.46-0.55$ and reliability value 0.887 .

Data collection was carried out in 2 places, which were in cardiac rehabilitation facility and Outpatient Care on a hospital in Bandung. Data were collected during February - April 2017. The research had the ethical clearance from the (sebutkan institusinya) number 177/ UN6.C10/PN/2017.

Data analysis was performed by using descriptive and inferential analysis. The univariate analysis used distribution frequency to analyze respondents' characteristics (age, gender, ethnicity, religion, habitation, occupation, education, marital status, income, possession of co-morbid disease, medical history, frequency of recurrence, cardiac rehabilitation participation status, perception of fitness, and perception of recurrence) and mean to analyze each of inhibiting factor. The bivariate analysis was performed by using Mann-Whitney test to identify the difference of inhibiting factors in both groups. This was because of the abnormal data distribution on respondents. 
Megalita : The Distinction of Inhibiting Factors among Patients who Actively and Inactively

\section{Result}

\section{The Characteristics of Respondents}

Most of the respondents was elderly (56-65 years old) and male, Moeslem, Sundanese ethnic, live with their spouse, in Bandung. More than half of respondents were working, had a moderate and high level of education, and more than $40 \%$ of respondents had monthly family income less than 2.8 million rupiah.
Table 2 was related to the characteristics of respondents based on the history of disease and their participation in the cardiac rehabilitation program. The majority of respondents $(68.1 \%)$ have been diagnosed for more than 6 months, more than half of respondents $(54 \%)$ did not have comorbid disease, and most of the participating respondents (95.9) had undergone medication and reperfusion therapy (fibrinolysis and Percutaneous Coronary Intervention (PCI) or

Table 1 Frequency Distribution of the Respondents Characteristics

\begin{tabular}{|c|c|c|c|}
\hline No & Characteristics & Frequency (f) & Percentage(\%) \\
\hline \multirow[t]{5}{*}{1.} & Age & & \\
\hline & Late adulthood (36-45 tahun) & 5 & 6.9 \\
\hline & Early elderly (46-55 tahun) & 21 & 29.2 \\
\hline & Elderly (56-65 tahun) & 37 & 51.4 \\
\hline & Late elderly ( $>65$ tahun) & 9 & 12.5 \\
\hline \multirow[t]{3}{*}{2.} & Gender & & \\
\hline & Male & 55 & 76.4 \\
\hline & Female & 17 & 23.6 \\
\hline \multirow[t]{3}{*}{3.} & Religion & & \\
\hline & Moeslem & 68 & 94.4 \\
\hline & Non-Moeslem & 4 & 5.6 \\
\hline \multirow[t]{3}{*}{4.} & Ethnicity & & \\
\hline & Sundanese & 55 & 76.4 \\
\hline & Non-Sundanese & 17 & 23.6 \\
\hline \multirow[t]{3}{*}{5.} & Domicile & & \\
\hline & $\begin{array}{l}\text { Bandung dan Bandung } \\
\text { Districts }\end{array}$ & 50 & 69.4 \\
\hline & $\begin{array}{l}\text { Outside of Bandung and } \\
\text { Bandung Districts }\end{array}$ & 22 & 30.6 \\
\hline \multirow[t]{4}{*}{6.} & Marital Status & & \\
\hline & Married & 65 & 90.3 \\
\hline & Not Married & 0 & 0 \\
\hline & Widow/Widower & 7 & 9.7 \\
\hline \multirow[t]{4}{*}{7.} & Level of Education & & \\
\hline & Low & 18 & 18.25 \\
\hline & Moderate & 27 & 37.5 \\
\hline & High & 27 & 37.5 \\
\hline \multirow[t]{3}{*}{8.} & Occupation & & \\
\hline & Unemployed & 34 & 47.3 \\
\hline & Employed & 38 & 52.8 \\
\hline \multirow[t]{2}{*}{9.} & Monthly Family Income & & \\
\hline & $<\operatorname{Rp} 2,8$ million & 29 & 40.3 \\
\hline
\end{tabular}


Megalita : The Distinction of Inhibiting Factors among Patients who Actively and Inactively

\begin{tabular}{lcc}
\hline Rp 2,8 million - Rp 5 million & 25 & 34.7 \\
$>$ Rp 5 million & 18 & 25 \\
\hline
\end{tabular}

Table 2 Respondents Clinical Characteristics

\begin{tabular}{|c|c|c|c|}
\hline No & Clinical Characteristics & Frequency (f) & Percentage (\%) \\
\hline \multirow[t]{3}{*}{1.} & Length of Diagnosed & & \\
\hline & $0-6$ month & 23 & 31.9 \\
\hline & $>6$ month & 49 & 68.1 \\
\hline \multirow[t]{3}{*}{2.} & Comorbid Disease & & \\
\hline & No & 39 & 54.2 \\
\hline & Yes & 33 & 45.8 \\
\hline \multirow[t]{4}{*}{3.} & History of Medication & & \\
\hline & Medication & 3 & 4.2 \\
\hline & Medication \& reperfusion therapy (PCI dan fibrinolysis) & 54 & 75 \\
\hline & Medication\& $\mathrm{CABG}$ & 15 & 20.9 \\
\hline \multirow[t]{7}{*}{4.} & Frequency of recurrence & & \\
\hline & Never & 24 & 33.3 \\
\hline & $<1$ time per week & 16 & 22.2 \\
\hline & $1-2$ times per week & 10 & 13.9 \\
\hline & $\geq 3$ times per week & 8 & 11.1 \\
\hline & $1-3$ times per day & 11 & 15.3 \\
\hline & $\geq 4$ times per day & 3 & 4.2 \\
\hline \multirow[t]{4}{*}{5.} & Participation in Cardiac Rehabilitation & & \\
\hline & Regularly & 38 & 52.8 \\
\hline & Irregularly & 34 & 47.2 \\
\hline & Never & 0 & 0 \\
\hline \multirow[t]{3}{*}{6.} & $\begin{array}{l}\text { Number of Attendance/Participation to Cardiac } \\
\text { Rehabilitation Facility }\end{array}$ & & \\
\hline & $\geq 6$ times & 36 & 50 \\
\hline & $<6$ times & 36 & 50 \\
\hline \multirow[t]{4}{*}{7.} & Perception of Fitness & & \\
\hline & Improve & 42 & 58.3 \\
\hline & No Changes & 6 & 8.3 \\
\hline & Decline & 24 & 33.3 \\
\hline \multirow[t]{6}{*}{8.} & Perception of Angina Recurrence & & \\
\hline & Not Worry & 20 & 27.8 \\
\hline & Rarely Worry & 17 & 23.6 \\
\hline & Worry & 18 & 25 \\
\hline & Frequently worry & 14 & 19.4 \\
\hline & Cannot stop being worry (Always worry) & 3 & 4.2 \\
\hline
\end{tabular}


Megalita : The Distinction of Inhibiting Factors among Patients who Actively and Inactively

ring installation).

Based on the cardiac rehabilitation participation, more than half of of respondents $(52.8 \%)$ participated cardiac rehabilitation phase II regularly. For the number of attendance, the number of both group were 36 people. More than a third of respondents $(33.3 \%)$ stated they had never experienced angina relapse. As many as $58.3 \%$ respondents stated that their fitness had improved caused by CR. And more than a quarter of respondents $(27.8 \%)$ expressed no concern about angina relapse.

\section{Overview of Cardiac Rehabilitation Participation}

Description of the participation of CHD patients in cardiac rehabilitation was analyzed by distribution frequency. The patient's participation status in cardiac rehabilitation program is based on inclusion criteria.
Based on table 3.3, it can be seen that there were 36 patients, either in the active or in the inactive group.

The Distinction of Inhibiting Factors in Active and Inactive Groups

The differences referred to the MannWhitney test, due to an abnormal distribution of data. The higher mean showed the higher barrier perceived by the group. The $\mathrm{P}$ value below 0.05 showed the differences that significantly perceived by the group.

The following table shows the results of the Mann-Whitney test of each question item that representing all four aspects. The higher mean showed the higher barrier perceived by the group. The P value below 0.05 showed the differences that significantly perceived by the group.

Table 3 The Frequency of Attendance in Cardiac Rehabilitation

\begin{tabular}{llccc}
\hline & & \multicolumn{2}{c}{$\begin{array}{c}\text { Participation to Cardiac } \\
\text { Rehabilitation }\end{array}$} & $\begin{array}{c}\text { Participation } \\
\text { Status }\end{array}$ \\
\cline { 3 - 4 } & & Regularly & Irregularly & \\
\hline Number of Attendance/ & $\geq 6$ meetings & 36 & 0 & Active $(50 \%)$ \\
Participation & $<6$ meetings & 2 & 34 & Inactive $(50 \%)$ \\
\hline
\end{tabular}

Table 4 The Distinction of Inhibiting Factors in Active and Inactive Patients based on MannWhitney Test $(n=72)$

\begin{tabular}{lccc}
\hline \multicolumn{1}{c}{ Sub Variabel } & Active Patients Group & Mean Inactive Patients Group & P value \\
\hline Healthcare Services Aspects & $2.19 \pm 0.51$ & $2.56 \pm 0.49$ & 0.002 \\
Logistics Aspects & $2.31 \pm 0.70$ & $2.59 \pm 0.72$ & 0.134 \\
Time Aspects & $2.14 \pm 0.67$ & $2.76 \pm 0.85$ & 0.001 \\
Functional Status Aspects & $2.15 \pm 0.61$ & $2.38 \pm 0.58$ & 0.057 \\
\hline
\end{tabular}

Table 5 The Distinction of Each Item Statement in Both Groups from Mann-Whitney Test Results $(n=72)$

\begin{tabular}{|c|c|c|c|c|}
\hline No & Statement & $\begin{array}{c}\text { Mean Active } \\
\text { Patient Group }\end{array}$ & $\begin{array}{l}\text { Mean Inactive } \\
\text { Patient Group }\end{array}$ & Pvalue \\
\hline \multirow[t]{6}{*}{1.} & Healthcare Services Aspects & & & \\
\hline & $\begin{array}{l}\text { I didn't know about cardiac rehab (e.g., } \\
\text { doctor didn't tell me about it) }\end{array}$ & 2.28 & 2.86 & 0.019 \\
\hline & $\begin{array}{l}\text { - } \quad \text { I don't need cardiac rehab (e.g., feel } \\
\text { well, heart problem treated, not serious) }\end{array}$ & 2.06 & 2.28 & 0.152 \\
\hline & $\begin{array}{l}\text { I already exercise at home, or in my } \\
\text { community }\end{array}$ & 2.33 & 2.86 & 0.023 \\
\hline & My doctor did not feel it was necessary & 1.97 & 2.44 & 0.001 \\
\hline & $\begin{array}{l}\text { Many people with heart problem don't } \\
\text { go, and they are fine }\end{array}$ & 2.24 & 2.53 & 0.031 \\
\hline
\end{tabular}


Megalita : The Distinction of Inhibiting Factors among Patients who Actively and Inactively

\begin{tabular}{|c|c|c|c|c|c|}
\hline & own & I can manage my heart problem on my & 2.36 & 2.61 & 0.202 \\
\hline & - & $\begin{array}{l}\text { I think I was referred, but the rehab } \\
\text { didn't contact me }\end{array}$ & 2.14 & 2.50 & 0.056 \\
\hline & the pro & $\begin{array}{l}\text { It took too long to get referred and into } \\
\text { ram }\end{array}$ & 2.11 & 2.56 & 0.014 \\
\hline & not in a & $\begin{array}{l}\text { I prefer to take care of my health alone, } \\
\text { group }\end{array}$ & 2.36 & 2.42 & 0.645 \\
\hline \multirow[t]{6}{*}{2.} & Logisti & s Aspects & & & \\
\hline & - & Distance & 2.53 & 2.81 & 0.239 \\
\hline & - & Cost & 2.19 & 2.42 & 0.219 \\
\hline & - & Transportation problems & 2.47 & 2.61 & 0.472 \\
\hline & $\begin{array}{l}- \\
\text { caregiv }\end{array}$ & $\begin{array}{l}\text { Family } \\
\text { ng) }\end{array} \quad$ responsibilities & 1.97 & 2.44 & 0.055 \\
\hline & - & Severe weather & 2.39 & 2.67 & 0.297 \\
\hline \multirow[t]{4}{*}{3.} & Time A & pects & & & \\
\hline & - & Travel (e.g., holidays, business, cottage) & 2.14 & 2.81 & 0.002 \\
\hline & inconve & $\begin{array}{l}\text { Time constraints (e.g., too busy, } \\
\text { nient class time) }\end{array}$ & 2.19 & 2.78 & 0.014 \\
\hline & - & Work responsibilities & 2.08 & 2.69 & 0.005 \\
\hline \multirow[t]{5}{*}{4.} & Functio & nal Status Aspects & & & \\
\hline & - & I find exercise tiring or painful & 2.06 & 2.33 & 0.072 \\
\hline & limitati & $\begin{array}{l}\text { I don't have the energy or physical } \\
\text { ons }\end{array}$ & 2.25 & 2.53 & 0.172 \\
\hline & - & Other health problems prevent me from & 2.11 & 2.33 & 0.115 \\
\hline & - & I am too old & 2.17 & 2.31 & 0.572 \\
\hline
\end{tabular}

\section{Discussion}

\section{The Distinctions of Inhibiting Factors in Active and Inactive Groups}

Hypothesis of this study is there were no differences or distictions of inhibiting factor between active group and inactive group who were undergoing phase II cardiac rehabilitation. Referring to the $\mathrm{p}$ value in table 3.4, ( $\mathrm{p}$ value $<0.05$ ), there were differences in inhibiting factors in active and inactive patients who were undergoing phase II cardiac rehabilitation. Based on the study findings the distinctions of inhibiting factors between active and inactive patients were in health services and time aspect. In the health services aspect, the most significant differences were in the statement of not knowing about cardiac rehabilitation $(\mathrm{p}$ value $=0.019)$ and the physicians do not recommend for cardiac rehabilitation $(\mathrm{p}$ value $=0.001)$.

In the statement of not knowing cardiac rehabilitation, the mean value in the active group was 2.28 , while in the inactive group was 2.86 . The difference of mean value was 0.59 . This happened because in active group only $16.7 \%$ of respondents agreed that lack of knowledge about cardiac rehabilitation became inhibitor, while in inactive group there were $36.1 \%$ of respondents who agreed that lack of knowledge about cardiac rehabilitation became inhibitor. This implied that the information about cardiac rehabilitation to the patients influenced their active participation on the program.

In a statement of the absence of a physician's referral to a cardiac rehabilitation facility, the mean for the active group was 1.97 , whereas in the inactive group the mean 
Megalita : The Distinction of Inhibiting Factors among Patients who Actively and Inactively

value was 2.44 . The difference of mean value was 0.47 . This occurred because as many as $2.8 \%$ of respondents in the active group agreed that absence of a referral from the physician to be an inhibitor, while in the inactive group $11.1 \%$ agreed that the absence of a referral from the physician made them did not attend the cardiac rehabilitation program. It concluded that reference plays a role in determining the participation of cardiac patients in rehabilitation programs.

The lack of respondents' knowledge about cardiac rehabilitation is influenced by the health providers, such as physicians and nurses (Clark et al., 2012). Respondents in the inactive group said they were not introduced and referred to cardiac rehabilitation facilities even though they had appropriate indications for starting physical activity again. This was in line and supported the results of the study, in which the respondents in the inactive group did not have adequate knowledge and also did not get a referral to participate cardiac rehabilitation, despite meeting the indications of cardiac rehabilitation.

This was in accordance with Clark's research (2012) which stated that one of the roles of medical personnel is to provide knowledge about cardiac rehabilitation. Health workers, whether physicians or nurses, should be able to provide knowledge about cardiac rehabilitation. It because the cardiac rehabilitation team consists of cardiologists, nurses, physiotherapists, and nutritionists (Olive, 2012). Providing health education on cardiac rehabilitation will improve knowledge about cardiac rehabilitation. Increasing the patient's knowledge of cardiac rehabilitation, especially regarding these benefits will improve patient compliance in cardiac rehabilitation. There are several way to increase patients participation by maximizing health workers role especially nurses' role as eduator and care giver. First, providing the information about cardiac rehabilitation directly during discharge planning (when the patient is finished undergoing hospitalization and will start outpatient treatment) becomes very important. Information can be spoken directly or through a leaflet that contains all information about cardiac rehabilitation (Hutchinson et al., 2015). The information provided should be given clearly, with consideration of respondent's characteristics that majority of respondents $(55.75 \%)$ had the low educational background.

Second, the other solutions to improve participation and adherence to cardiac rehabilitation programs are to allow patients who are not recommendations from a doctor but have a history that includes an indication of cardiac rehabilitation to be examined and follow cardiac rehabilitation. The role of the nurse will be very important, because the patients' assessment must be done very carefully. Automatic referrals for all CHD patients who meet the criteria for cardiac rehabilitation may also be a solution to increasing participation and adherence to cardiac rehabilitation (Clark et al., 2012).

In the time aspect, the differences were in the three statement items representing the time aspect, there were other activities/ schedules $(\mathrm{p}$ value $=0.002)$, limited time $(\mathrm{p}$ value $=0.014)$, and work $(\mathrm{p}$ value $=0.005)$. A significant difference in time aspect occurred because many patients complain of a cardiac rehabilitation schedule which was not in 2 consecutive days, e.g.: Monday and Tuesday but what has happened the schedule was on Monday and Wednesday. This made the patient felt reluctant because there were other activities/schedules, had limited time, or work. There was a difference in mean value as much as 0.67 on the statement "there are other activities/schedules". This was because as much as $30.6 \%$ of patients in the inactive group agreed that other activities/schedules became inhibitor, while in the active group only $16.7 \%$ agreed that other activities/ schedules were inhibitors. Then, for "work" statement, the mean value difference was 0.61 . This was because as much as $50 \%$ of respondents from both groups were still actively working, so doing therapy with 1 or 2 days interval will difficult to them to take work permission. But in the active group, many of respondents rescheduled to the same week so they continued to attend regular cardiac rehabilitation meetings per week, while inactive groups did not. This information can be seen from the CR daily meeting list. This condition distinguished the participation of both groups in terms of time. It showed that motivation to participate in CR between active and inactive group was different, and it 
Megalita : The Distinction of Inhibiting Factors among Patients who Actively and Inactively

should be proven by other study. Furthermore related to these conditions, it is necessary to consider other cardiac rehabilitation centers in the regions so that patients can save time to come even though they must be done CR program several times a week.

Then, for "limited time" statement, the mean difference of the two groups was 0.59 . This was because as much as $30.6 \%$ of respondents in the active group agreed the limited time was inhibiting, while in the active group only $22.2 \%$. This was also in accordance with Brual et al. (2007) who stated that the average patient's driving time for a $25 \mathrm{~km}$ distance to a cardiac rehabilitation center in Ontario, Canada was about $60-80$ minutes. The average distance of respondents who live in the city and district of Bandung to cardiac rehabilitation center is about 25 $\mathrm{km}$. If the distance is converted to time, the respondents who live in the city and district of Bandung could spend \pm 1 hour trip.

Based on the interview to the respondents, It was known that respondents who live outside the city/district of Bandung, in active groups, they chose to rent a rent house/boarding house close to the cardiac rehabilitation facility or lived in their relative's houses in Bandung so they can save the time. However, in the inactive group, the respondents who live outside the city/district of Bandung, they had to travel more than $25 \mathrm{~km}$, when converted to time, they could spend \pm 3 hours trip. This travel time is also influenced by the geographical characteristics of Bandung which is a big city, traffic jams happened so often, the lack of public transport facilities from the respondents' location, and also the underconstruction roads condition. It can prolong the travel time to cardiac rehabilitation. It also distinguished the participation of cardiac rehabilitation in both groups.

This condition reinforces the importance of CR facilities made in the regions, or in the community centers or home based settings.

This condition reinforces the importance of CR facilities made in the regions, or in the community centers or home based settings to overcome the obstacle from time aspect. The Community and home based cardiac rehabilitation can be possible implemented, by training and empowerment of health workers and nurses on the concept and measurement of cardiac rehabilitation to health workers and nurses (Daskapan, 2005; Mandic et al., 2013; Mosleh, Bond, Lee, Kiger, \& Campbell, 2014). Cardiac rehabilitation at home and community has also increased the percentage of attendance at each session as many as $98 \%$ for those who do at home and $81 \%$ for those who do in the hospital (Daskapan, 2005). Oerkild (2012) mentioned that patients who perform cardiac rehabilitation at home will experience an increase in physical capacity seen from the results of the walking test for 6 minutes as many as 33.5 meter.

However, the benefits of cardiac rehabilitation will only increase participation continuously because of the benefits of cardiac rehabilitation are increase the external motivation (Jane \& Doust, 2015). To improve the internal motivation, knowledge of cardiac rehabilitation is required (Lima et al., 2015). Meanwhile in the results of this study, knowledge of cardiac rehabilitation had different results in both groups, which is the inactive group had less knowledge than the active group. So, to increase the number of participation in the inactive group, the health workers which is cardiac rehabilitation team, especially nurses have to provide the knowledge about cardiac rehabilitation from the very beginning when the patients have been diagnosed with CHD or when the patients have been hospitalized caused by CHD.

\section{Research Limitation}

Limitation of this study was the method of determining the criteria of active and inactive patients. Due to the existing concepts of cardiac rehabilitation, the active patients should be those who had followed cardiac rehabilitation during 12 regular meetings. However, in fact, there was no patient had followed 12 meetings. Most patients who came were those who had followed 6 or more meetings. Another limitation was the generalizability because this study only held at one cardiac rehabilitation center in West Java. 
Megalita : The Distinction of Inhibiting Factors among Patients who Actively and Inactively

\section{Conclusion}

The results showed that there were distinctions in inhibiting factors in the active and inactive groups undergoing phase II cardiac rehabilitation in Bandung. The differences were in health services and time aspects, whereas in other aspects there were no differences found. The item statements that had significant differences were: from the health services aspect were a statement of "not knowing about cardiac rehabilitation and the physicians recommendations", while from the time aspect were "there are other activities/schedules, limited time, and work".

\section{References}

Casey, E., Hughes, J.W., Waechter, D., Josephson, R., \& Rosneck, J. (2008). Depression predicts failure to complete phase-II cardiac rehabilitation. Journal of Behavioral Medicine, 31(5), 421-431. http:// doi.org/10.1007/s10865-008-9168-1.

Chou, C.L., Lee, S.H., Su, Y.T., Hong, S.Y., Pan, B.R., \& Chan, R.C. (2014). Impact of phase II cardiac rehabilitation on abnormal heart rate recovery. Journal of the Chinese Medical Association, 77(9), 482-486. http:// doi.org/10.1016/j.jcma.2014.06.004.

Clark, A.M., King-shier, K.M., Duncan, A., Spaling, M., Stone, J.A., Jaglal, S., \& Angus, J. (2012). Factors influencing referral to cardiac rehabilitation and secondary prevention programs: A systematic review. http://doi.org/10.1177/2047487312447846.

Daskapan, H.H.A., Caglar, N.N.T., \& Ataman, S. (2005). Comparison of supervised exercise training and home based exercise training in chronic heart failure. Saudi Med Journal, 26, 842.

Grace, S.L., Gravely-Witte, S., Brual, J., Monette, G., Suskin, N., Higginson, L., ..., Stewart, D.E. (2011). Contribution of patient and physician factors to cardiac rehabilitation enrollment: A prospective multilevel study. European Journal of Cardiovascular Prevention and Rehabilitation: Official
Journal of the European Society of Cardiology, Working Groups on Epidemiology \& Prevention and Cardiac Rehabilitation and Exercise Physiology, 15, 548-556. http://doi. org/10.1097/HJR.0b013e328305df05.

Grace, S.I., Shanmugaseragaram, S., Gagliese, L., Oh, P., Stewart, D.E., Brister, S.J., et al. (2011). Psychometric validation of the Cardiac Rehabilitation Barriers Scale. Clinical Rehabilitation, 152-164.

Harlan, W.R., Sandler, S.A., Lee, K.L., Lam, L.C., \& Mark, D.B. (1995). Importance of baseline functional and socioeconomic factors for participation in cardiac rehabilitation. American Journal of Cardiology, 76(1), 36-39. http://doi.org/10.1016/S00029149(99)80797-8.

Hutagalung, R.U., Susilaningsih, F.S., \& Mardhiyah, A. (2013). Kualitas hidup pasien pascaintervensi koroner perkutan. Jurnal Keperawatan Padjadjaran, 2(1).

Hutchinson, P., Meyer, A., \& Marshall, B. (2015). Factors Influencing Outpatient Cardiac Rehabilitation Attendance, 360-367. http://doi.org/10.1002/rnj.202.

Indonesian Heart Assossciation. (2015). Pedoman tatalaksana sindrome koroner akut, 88. http://doi.org/10.1093/eurheartj/ehn416.

Jane, R., \& Doust, J.H. (2015). Motivational processes and well-being in cardiac rehabilitation: A self-determination theory perspective. Journal Psychology, Health \& Medicine, 20(5), 518-529.

Lima, G., Ghisi, D.M., Grace, S.L., Thomas, S., Vieira, A.M., Costa, I.Z., \& Oh, P. (2015). Knowledge and exercise behavior maintenance in cardiac rehabilitation patients receiving educational interventions. Heart and Lung The Journal of Acute and Critical Care, 44(6), 474-480. http://doi. org/10.1016/j.hrtlng.2015.09.004.

Mandic, S., Hodge, C., Stevens, E., Walker, R., Nye, E.R., Body, D., ..., Williams, M.J.A. (2013). Effects of community-based cardiac rehabilitation on body composition and 
Megalita : The Distinction of Inhibiting Factors among Patients who Actively and Inactively

physical function in individuals with stable coronary artery disease: 1.6-year follow up.

Ministry of Health RI. (2013). Riset kesehatan dasar. Cited April 04, 2016, dari Badan Litbang Kesehatan Kementrian Kesehatan.

Mosleh, S.M., Bond, C.M., Lee, A.J., Kiger, A., \& Campbell, N.C. (2014). Effectiveness of theory-based invitations to improve attendance at cardiac rehabilitation: A randomized controlled trial. Eur $J$ Cardiovasc Nurs, 3(3), 201-10. doi: $10.1177 / 1474515113491348$.

Nuraeni, A., Mirwanti, R., Anna, A., Prawesti, A., \& Emaliyawati, E. (2016). Faktor yang memengaruhi kualitas hidup pasien dengan penyakit jantung koroner. Jurnal Keperawatan Padjadjaran, 4(2). Retrieved from http://jkp.fkep.unpad.ac.id/index.php/ $\mathrm{jkp} /$ article/view/231/123.

Olive. (2012). Cardiac rehab- alive after thirty five 2012-2015. Cited February 2016, dari http://www.aliveafter35.com.

Pasquali, S.K., Alexander, K.P., Coombs, L.P., Lytle, B.L., \& Peterson, E.D. (2003). Effect of cardiac rehabilitation on functional outcomes after coronary revascularization. American Heart Journal, 145(3), 445-451. http://doi.org/10.1067/mhj.2003.172.

Piotrowicz, R., \& Wolszakiewicz, J. (2008). Cardiac rehabilitation following myocardial infarction. Cardiology Journal, 15(5), 481-7.
Radi, B., Joesoef, A.H., \& Kusmana, D. (2009). Rehabilitasi kardiovaskular di Indonesia. Jurnal Kardiologi Indonesia, 30(2), 43-45.

Rosidawati, I., Ibrahim, K., \& Nuraeni, A. (2016). Kualitas hidup pasien pasca bedah pintas arteri koroner (BPAK). Jurnal Keperawatan Padjadjaran, 4(2). Retrieved from http://jkp.fkep.unpad.ac.id/index.php/ $\mathrm{jkp} /$ article/view/238/132.

SIGN. (2002). Cardiac rehabilitation: $A$ national clinical guideline. Scotland: Scottish Intercollegiate Guidelines Network.

Taylor, R.S., Brown, A., Ebrahim, S., Jolliffe, J., Noorani, H., Rees, K., ..., Oldridge, N. (2004). Exercise-based rehabilitation for patients with coronary heart disease: Systematic review and meta-analysis of randomized controlled trials. American Journal of Medicine. http://doi.org/10.1016/j. amjmed.2004.01.009.

WHO. (2013). Global health obeservatory data repository-kardiovaskular diseases, death per 100.000 data by Country. Cited Februari 2016, dari: http://apps.who.int/gho/ data/node.main.A865KARDIOVASKULAR.

WHO. (2015). Global health obeservatory data repository-kardiovaskular diseases, death per 100.000 data by Country. Cited Februari 2016, dari: http://apps.who.int/gho/ data/node.main.A878KARDIOVASKULAR. 